\title{
In vivo assessment of possible probiotic properties of Zymomonas mobilis in a Wistar rat model
}

\author{
Geíza Alves de Azerêdo \\ Departamento de Nutrição \\ Centro de Ciências da Saúde \\ Universidade Federal de Pernambuco \\ Recife, Brasil
}

\author{
Tânia Lúcia Montenegro Stamford \\ Departamento de Nutrição \\ Centro de Ciências da Saúde \\ Universidade Federal de Pernambuco \\ Recife, Brasil

\section{Evandro Leite de Souza* \\ Departamento de Nutrição \\ Centro de Ciências da Saúde \\ Universidade Federal da Paraíba \\ João Pessoa, Paraíba, Brasil} \\ E-mail: evandroleitesouza@ccs.ufpb.br
}

\section{Flávio Fonseca Veras}

Departamento de Ciências Biológicas Centro de Ciências Biológicas

Universidade Federal de Pernambuco Recife, Brasil

\section{Edvaldo Rodrigues de Almeida \\ Departamento de Antibióticos \\ Centro de Ciências Biológicas \\ Universidade Federal de Pernambuco Recife, Brasil}

\section{Janete Magali de Araújo}

Departamento de Antibióticos Centro de Ciências Biológicas

Universidade Federal de Pernambuco Recife, Brasil

Financial support: Coordenação de Aperfeiçoamento de Pessoal de Nível Superior - CAPES (Brazil).

Keywords: health benefit, safety, Zymomonas mobilis.

Abbreviations: cfu: colony forming units

EDTA: Ethylenediamine tetraacetic acid

SDDL: Standard Swings \& De Ley

In recent years the incorporation of probiotic bacteria into foods has received increasing scientific interest for health promotion and disease prevention. The safety and probiotic properties of Zymomonas mobilis CP4 (UFPEDA-202) was studied in a Wistar rat model fed the $10^{9}$ colony forming units $(\mathrm{cfu}) / \mathrm{mL}^{-1}$ of the assayed strain for 30 days. No abnormal clinical signs were noted in the group receiving viable cells of $Z$. mobilis and water (control) during the period of the experiment. There were no significant difference $(p>0.05)$ in feed intake and weight gain among mice fed the $Z$. mobilis in comparison to the control group. No bacteria were found in blood, liver and spleen of any animals. Mice receiving $Z$. mobilis showed significantly differences $(p<$ 0.05 ) in total and differential leucocytes count, excepting for neutrophils, after the experimental period. Otherwise, it was not found in control group. Histological examination showed that feeding mice with $Z$. mobilis caused no signs of adverse effects on gut, liver and spleen. From these results, $Z$. mobilis CP4

\footnotetext{
*Corresponding author
} 
(UFEPEDA-202) is likely to be nonpathogenic and safe for consumption, and could have a slight modulating effect on immunological performance in mice.

In recent years there has been a steadily increasing community interest in health promotion and disease prevention, and one specific approach attracting increasing interest amongst consumers and the food industry has been the incorporation of probiotic bacteria into foods (Montesi et al. 2005). According to FAO/WHO (Fuller, 1989), probiotics are "live microorganisms which when administered in adequate amounts confer a health benefit on the host”.

Therefore, the generally recognized as safe (GRAS) status of newly isolated organisms with no previous history has to be confirmed by safety studies using target animals prior to being incorporated into feed products (Conway, 1996; Collins et al. 1998; Zhou et al. 2000). No general guidelines for the safety assessment of a novel probiotic strain exist at this stage, and the type of tests that should be included has warranted a much debate (Saarela et al. 2000). More recent studies have promoted probiotic specific safety evaluation criteria, especially the infectivity, metabolic activity and immune function of a probiotic strain (O’Brien et al. 1999; Huang et al. 2003).

Zymomonas mobilis is a Gram-negative, facultative anaerobic bacterium that ferments glucose, fructose, and sucrose as carbon sources (Viikari and Berry, 1988). These carbohydrates are metabolized via the same biochemical route, the Entner-Doudoroff pathway. Z. mobilis are rods 2$6 \mu \mathrm{m}$ in length and 1-1.5 $\mu \mathrm{m}$ in width, flagellated but lack spores or capsules and growing in a $\mathrm{pH}$ range of 3.4-7.5 (De Paula et al. 2008). Z . mobilis at $10^{9}$ colony forming units per $\mathrm{mL}$ (cfu/mL) has already been previously studied, and its antagonistic effects in vitro and in animal model against bacteria, fungi and protozoa are known (Lima, 1958; Lima et al. 1969; Souza and Souza, 1973; Santos et al. 2004), however its mechanism remains to be found.

Still, Z. mobilis has received a current attention due to its capability to produce the exopolysaccharide levan for a large scale (Bekers et al. 2002; Oliveira et al. 2007). Levan have a wide variety of applications and can be used in medicine as a hypo-cholesterol (Yamamoto et al. 1999), antitumor (Calazans et al. 1997), immune modulator (Yoo et al. 2004) and anti-inflammatory agent (Vigants et al. 2001).

This study was undertaken to evaluate the probiotic properties and safety of Z. mobilis CP4 (UFPEDA-202) in a rat model regarding, i) measurement of general health; ii) hematological parameters; iii) histological examination, and iv) bacterial translocation. To our knowledge, the probiotic potentiality and safety of Z. mobilis CP4 (UFPEDA-202) has not been assessed to date.

\section{MATERIALS AND METHODS}

\section{Microorganism}

Zymomonas mobilis CP4 (UFPEDA-202) gently supplied by Microorganism Collection, Department of Antibiotics, Federal University of Pernambuco (Recife, Brazil) was used as control positive in this study. The strain was kept on Standard Swings and De Ley - (glucose 20.0; yeast extract 5.0; agar $15 \mathrm{~g} \mathrm{~L}^{-1}$ ) (Swings and De Ley, 1977) under refrigeration. For experimental assays the strain was grown in SDDL broth (glucose 20.0; yeast extract; $5.0 \mathrm{~g} \mathrm{~L}^{-1}$ ) at $30^{\circ} \mathrm{C}$ for $48 \mathrm{hrs}$. The number of viable cells $(\mathrm{cfu} / \mathrm{mL})$ was determined by the agar plate method using Schreder agar

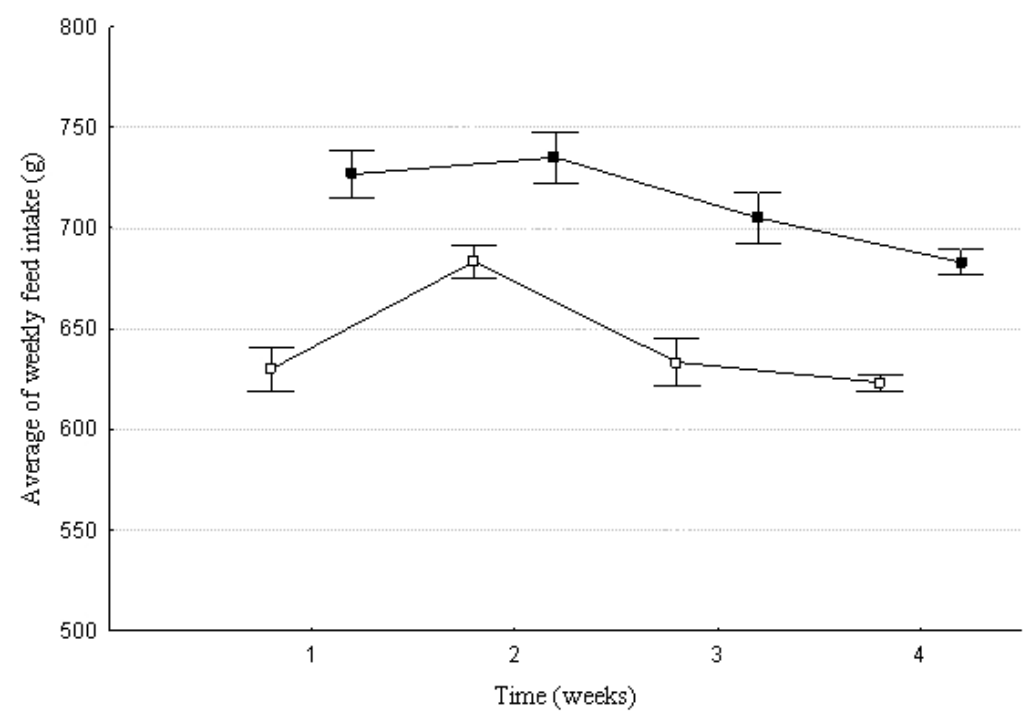

Figure 1. Average of weekly feed intake of mice orally fed the Z. mobilis CP4 (UFEPEDA-202) (daily dose of $10^{9} \mathrm{cfu} / \mathrm{mL}$ ) or waterfor 30 days ( $\square$ : control; a: treatment). 
Table 1. Feature of general health appearance score (Shu et al. 1999).

\begin{tabular}{|l|c|}
\hline \multicolumn{1}{|c|}{ General health appearance } & Score \\
\hline $\begin{array}{l}\text { Mouse bright-eyed alert, has a smooth coat with a sheen, responds to stimulus, shows } \\
\text { interest in its environment }\end{array}$ & 1 \\
\hline Fur slightly ruffled, a loss of sheen to the coat, mouse remains alert and active & 2 \\
\hline $\begin{array}{l}\text { Fur noticeably ruffled, parts of coat from clumps, mouse not as alert or active, less } \\
\text { interested in environment outside of cage, signs of hyperventilating when handled }\end{array}$ & 3 \\
\hline \begin{tabular}{l} 
Mouse hunched over and sleepy, little interest shown in environment, fur clumped \\
\hline $\begin{array}{l}\text { Mouse non-reactive to stimulus, fur has a "bottle brush" appearance, i.e., standing on } \\
\text { end, mouse hunched over preferring to sleep rather than react to environment, mouse } \\
\text { cold to touch, paws are cold to touch }\end{array}$
\end{tabular} \\
\hline
\end{tabular}

$\left(\mathrm{MgSO}_{4} .7 \mathrm{H}_{2} \mathrm{O} \quad 0.5 ; \quad\left(\mathrm{NH}_{4}\right) \mathrm{SO}_{4} \quad 1.0 ; \mathrm{K}_{2} \mathrm{HPO}_{4} \quad 1.0 ;\right.$ yeast extract 1.0; sucrose 20; agar $15 \mathrm{~g} \mathrm{~L}^{-1}$ ) incubated for $24 \mathrm{hrs}$ at $30^{\circ} \mathrm{C}$ (Swings and De Ley, 1977).

\section{Animals}

In this study, 40 (five week-old) male Wistar mice (Rattus novergicus) bred at the Animal Production Division, Department of Antibiotics, Federal University of Pernambuco (Recife, Brazil) were chosen regarding immunity, infection and health general aspects. Mice included in this study were born to normal, healthy mothers, and were given access to normal rat chow until weaning. Animals were divided at random into two groups (n: 20), one for each treatment. Animals were housed at controlled temperature $\left(23 \pm 2^{\circ} \mathrm{C}\right)$ with a $12 \mathrm{hrs}$ light/dark cycle and were offered standard diet (moisture 13; raw protein 23; fat 4; ashes 10; fiber 5; calcium 1.3; phosphorus $0.85 \mathrm{~g} .100 \mathrm{~g}^{-1}$ ) and water ad libitum. Experimental protocols including the use of animals were according to the procedures described by National Institute of Health Guide for Care and Use of Laboratory Animals - USA adopted by "Comissão em Ética and Experimentação Animal - CEEA” of the Federal University of Pernambuco (Recife, Brazil).

\section{Experimental design}

Double-blind experimental design included two treatments: I) probiotic treatment: mice were daily fed the $1 \mathrm{~mL}$ of $Z$. mobilis suspension $\left(10^{9} \mathrm{cfu} / \mathrm{mL}\right)$ in sterile distilled water daily + standard diet for thirty days; II) non-probiotic treatment: mice were daily fed the $1 \mathrm{~mL}$ of sterile distilled water daily + standard diet for thirty days. For administration of $Z$. mobilis new feed stocks were generated each day in SDDL broth and their viability monitored by the viable cell count using Schreder agar.
Animals were euthanized humanely by an overdose of isofluorane after 30 days of treatment for determining bacterial translocation and to histological examination. Haematological analysis were performed before (zero time) and after thirty days of feeding treatment.

\section{Measurement of general health}

The general health appearance of the mice was daily monitored using a score system of 1 to 5 (Table 1). Feed intake and body weight were recorded once a week. Occurrence of diarrhea and vomiting was monitored daily.

\section{Bacterial translocation assays}

A $1 \mathrm{~mL}$ of blood was collected by cardiac punctureand added to $10 \mathrm{~mL}$ of sterile SDDL broth for $48 \mathrm{hrs}$ at $37^{\circ} \mathrm{C}$. Tissue samples of spleen and liver were aseptically collected into a set $5 \mathrm{~mL}$ sterile tubes containing $3 \mathrm{~mL}$ of SDDL broth and incubated for 24 hrs at $37^{\circ} \mathrm{C}$. After that, a $0.1 \mathrm{~mL}$ was plated on selective Schreder agar for $48 \mathrm{hrs}$ at $37^{\circ} \mathrm{C}$ for count of $\mathrm{Z}$. mobilis. At the end of the incubation period, plates were observed and the results were expressed as positive (presence of bacteria on plates) or negative (absence of bacteria on plates) bacterial translocation.

\section{Histological examination}

Tissue samples of liver, spleen and gut were aseptically

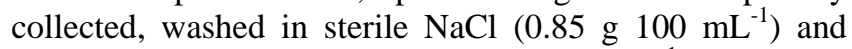
fixed in neutral buffer formalin (10 g $\left.100 \mathrm{~mL}^{-1}\right)$ for $48 \mathrm{hrs}$. Thereafter, samples were dehydrated in alcohol, cleared in xylene and embedded in paraffin wax. Six sections $(4 \mu \mathrm{m}$ thick) from each organ were cut and stained by hematoxylin and eosin (Thermo Shandon, 1527, USA). The slides prepared with synthetic resin (Entellan-Merck) were observed under light microscopy up to $100 \mathrm{x}$. 


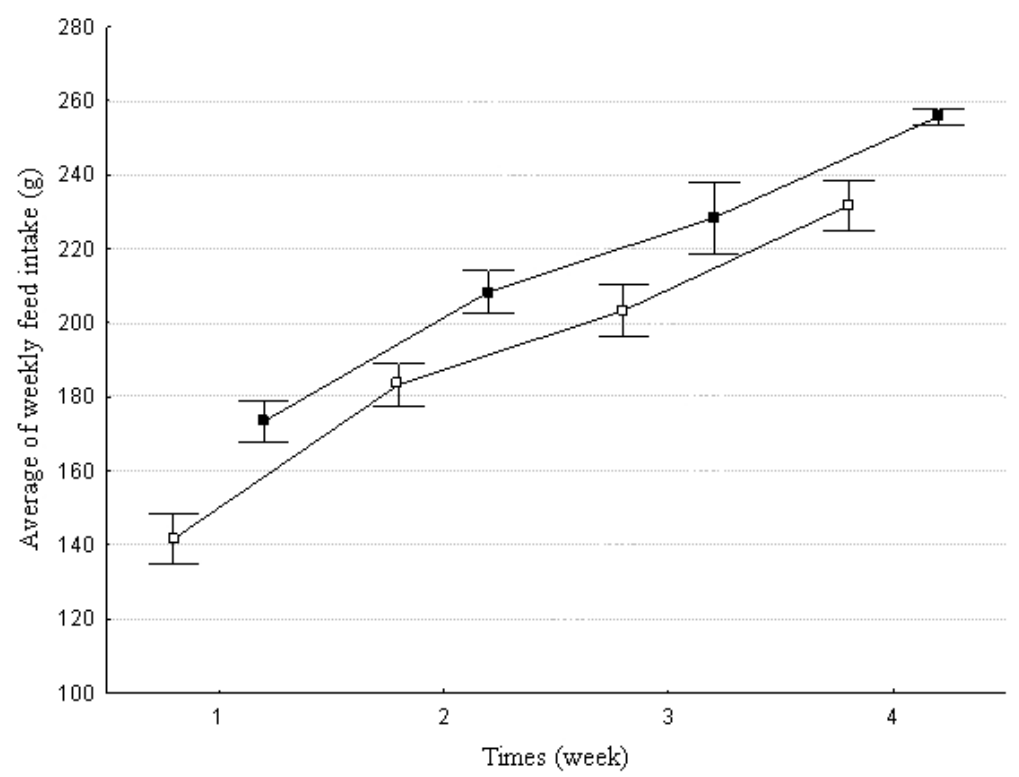

Figure 2. Cumulative specific average of weight weekly gain of mice orally fed the $Z$. mobilis CP4 (UFEPEDA-202) (daily dose of $10^{9} \mathrm{cfu} / \mathrm{mL}$ ) or water for 30 days ( $\square$ : control; $\square$ : treatment).

\section{Total and differential leukocyte count}

From previously anesthetized animals using ethylic-alcohol a $100 \mu \mathrm{L}$ of blood was taken using sterile $2 \mathrm{~mL}$ syringes rinsed first with EDTA $\left(2.7 \mathrm{~g} 100 \mathrm{~mL}^{-1}\right)$. The blood aliquot was put in Eppendorf tubes coated with $20 \mu \mathrm{L}$ of EDTA (2.7 g $\left.100 \mathrm{~mL}^{-1}\right)$. Total and differential leukocyte count was performed at the Laboratory of Clinical Analysis, Department of Pharmacy, Federal University of Pernambuco (Recife, Brazil) according to standard haematological procedures.

\section{Statistical analysis}

Statistical analysis was carried out by analysis of covariance (ANCOVA) to determine significant difference (p $<0.05)$ between the data sets. For this, was used the Statistical Package for Social Sciences version 11.0.

\section{RESULTS AND DISCUSSION}

Data on feed intake of mice receiving $10^{9} \mathrm{cfu} / \mathrm{mL}$ of viable cells of Z. mobilis CP4 (UFEPEDA-202) or water are shown in Figure 1. There was not statistical difference ( $p>$ 0.05 ) for feed intake for mice receiving viable cells of $Z$. mobilis or water. Data on the average weight gain of mice receiving $10^{9} \mathrm{cfu} / \mathrm{mL}$ of viable cells of $Z$. mobilis CP4 (UFEPEDA-202) or water for 30 days are shown in Figure 2. Statistical analysis revealed no significant difference ( $\mathrm{p}>$ 0.05 ) in weight gain between groups submitted to the different treatments.

Trials investigating some potentially probiotic bacteria strains did not detect enhanced growth performance of mice with enriched diet (Zhou et al. 2000). With regard to the growth-stimulating effects of probiotic bacteria, some authors have reported that a probiotic response is more likely to be obtained in situations involving negative stress of some kind (Thomke and Elwinger, 1998). Research exploiting the availability of malnourished murine models has also demonstrated the beneficial effects of administering probiotics in preventing stress-related weight loss (Perdigón et al. 1995).

Throughout the experiment mice appeared to be healthy, inquisitive and active. It was also indicated by their food intake, weight gain and general appearance. No illness or death occurred and there were no signs of gastrointestinal upsets including diarrhea or vomiting. The mean general health score did not differ significantly between mice fed the Z. mobilis and non-fed (control) (data not showed).

These findings are consistent with previous studies which in addition for noting no difference in feed intake and weight gain reported the occurrence of no adverse clinical signs in probiotic-fed mice (Shu et al. 1999, Zhou et al. 2000).

Data on the total and differential leukocytes average count of mice receiving $10^{9} \mathrm{cfu} / \mathrm{mL}$ of viable cells of Z. mobilis CP4 (UFEPEDA-202) after thirty days of feed are shown in Table 2. Treated group showed statistical differences ( $\mathrm{p}<$ 0.05 ) in total and differential leucocytes count after receiving $Z$. mobilis for 30 days, excepting for neutrophils. Otherwise, it was only found for eosinophils and monocytes in the control group. Some studies have shown that probiotic bacteria can have positive effects on the immune system of their host (Blum et al. 1999; Gill et al. 
Table 2. Average count of total and differential leukocytes of mice orally fed the $Z$. mobilis CP4 (UFPEDA-202) (daily dose of $10^{9} \mathrm{cfu} / \mathrm{mL}$ ) and water (control) during 30 days.

\begin{tabular}{|c|c|c|c|c|c|c|}
\hline \multirow{2}{*}{ Leukocytes } & \multicolumn{2}{|c|}{$\begin{array}{c}\text { Average } \\
\text { (D0 - D30) }\end{array}$} & \multicolumn{2}{c|}{ Standard deviation } & \multicolumn{2}{c|}{ Significance } \\
\cline { 2 - 7 } & Control & Treatment & Control & Treatment & Control & Treatment \\
\hline Total leukocytes & 1030.00 & 1630.00 & 1902.659 & 2279.401 & 0.082 & 0.050 \\
\hline Neutrophils & -277.70 & -254.80 & 1463.745 & 945.281 & 0.370 & 0.416 \\
\hline Eosinophils & -107.60 & -110.50 & 137,726 & 132.016 & 0.036 & 0.027 \\
\hline Linphocytes & 890.20 & 1631.40 & 1305.134 & 1954.387 & 0.073 & 0.027 \\
\hline Monocytes & 344.50 & 363.90 & 151.329 & 134.651 & 0.000 & 0.000 \\
\hline
\end{tabular}

D0: day zero; D30: day thirty

2000). However, differences between different probiotic bacteria in respect to their immunomodulatory effects have been also observed (Médici et al. 2004). The immunomodulation mediated by probiotic strains is expected to be not linked to an inflammatory response or general modification of immune responsiveness that could potentially have harmful effects, but to be rather associated with transient alterations beneficial to the consumer (Saarela et al. 2000).

Infectivity and pathogenicity are two important components in safety studies on probiotic bacteria. Increase in peripheral blood neutrophils is useful indicator of bacterial infection (Zhou et al. 2000). In this study it was not detected higher levels of neutrophils in mice receiving $Z$. mobilis CP4 (UFEPEDA-202) for thirty days. These results could suggest that mice experienced no infection resulting from the treatment with this strain.

Histological examination (toxicological effects) showed that feeding mice with Z. mobilis CP4 (UFEPEDA-202) caused no signs of inflammation, degeneration or necrosis of the intestinal mucosa. Macroscopic examination did not reveal any obvious differences in the size and appearance of visceral organs between each experimental group. No hepatomegaly or splenomegaly was noted (data not showed).

No viable cell of Z. mobilis CP4 (UFEPEDA-202) was detected from blood, spleen and liver sample taken from animals of the two experimental groups, which indicates absence of bacterial translocation (data not showed). These findings suggest that feeding mice with $Z$. mobilis did not result in extra-intestinal dissemination. Bacterial translocation refers to the phenomenon in which the intestinal bacteria pass through the mucosal epithelium to be transported to the lamina propria, mesentery lymph nodes and other organs, and may further cause bacteriaemia, septicaemia and even multiple organ failure (Berg, 1992). Translocation is an indicator of potential pathogenicity for most obligate and facultative pathogens (Zhou et al. 2000).

Safety is the most important criterion for selection of new probiotic strains, and there has been considerable debate on appropriate safety testing for new probiotic strains proposed for human consumption (Saarela et al. 2000). Of the safety criteria currently proposed for probiotics, the absence of pathogenicity and infectivity is regarded as the most important factor for consideration (Conway, 1996; Huang et al. 2003). In our study, to test the pathogenicity and infectivity of $Z$. mobilis CP4 (UFEPEDA-202), recommended safety testing was undertaken, including measurement of bacterial translocation to blood and extraintestinal organs, and the occurrence of histological alteration in tissues.

These results suggest that strain of $Z$. mobilis CP4 (UFEPEDA-202) is likely to be nonpathogenic and safe for consumption, and could have a slight beneficial effect on immunological performance in mice. Still, it supports the purpose for continuing researches focusing on the use of this strain for health-promoting purpose by the formulation of functional foods.

\section{REFERENCES}

BEKERS, M.; LAUKEVICS, J.; UPITE, D.; KAMINSKA, E.; VIGIANTS, A.; VIESTURS, U.; PANKOVA, L. and DANILEVICS, A. Fructooligosaccharide and levan producing activity of Zymomonas mobilis extracellular 
levansucrase. Process Biochemistry, December 2002, vol. 38, no. 5, p. 701-706.

BERG, Rodney D. Translocation and the indigenous gut flora. In: FULLER, Ray. ed. Probiotics: The scientific basis. London; Chapman and Hall, 1992, p. 55-85.

BLUM, S.; DELNESTE, Y.; ALVAREZ, S.; HALLER, D.; PEREZ, P.F.; BODE, C.; HAMMES, W.P.; PFEIFER, A.M.A. and SCHIFFRIN, E.J. Interactions between comensal bacteria and mucosal immunocompetent cells. International Dairy Journal, January 1999, vol. 9, no. 1, p. 63-68.

CALAZANS, G.M.T.; LOPES, C.E.; LIMA, R.O.C. and FRANÇA, F.P. Antitumour activities of levans produced by Zymomonas mobilis strains. Biotechnology Letters, January 1997, vol. 19, no. 1, p. 19-21.

COLLINS, J.K.; THORTON, G. and SULLIVAN, G.O. Selection of probiotics strains for human applications. International Dairy Journal, May 1998, vol. 8, no. 5-6, p. 487-490.

CONWAY, Patricia L. Selection criteria for probiotic microorganisms. Asia Pacific Journal of Clinical Nutrition, 1996, vol. 5, no. 1, p. 10-14.

DE PAULA, Valdemir C.; PINHEIRO, Irapuan O.; LOPES, Carlos E. and CALAZANS, Glícia Maria T. Microwave-assisted hydrolysis of Zymomonas mobilis levan envisaging oligofructan production. Bioresource Technology, May 2008, vol. 99, no. 7, p. 2466-2470.

FULLER, Ray. Probiotics in man and animals. Journal of Applied Bacteriology, 1989, vol. 66, no. 5, p. 365-378.

GILL, Harsharnjit S.; RUTHERFURD, Kay J.; PRASAD, Jaya and GOPAL, Pramod K. Enhancement of natural and acquired immunity by Lactobacillus rhamnosus (HN001), Lactobacillus acidophilus (HN017) and Bifidobacterium lactis (HN019). British Journal of Nutrition, February 2000, vol. 83, no. 2, p. 167-176.

HUANG, Yang; KOTULA, Lidija and ADAMS, Michelle C. The in vivo assessment of safety and gastrointestinal survival of an orally administered novel probiotic, Propionibacterium jensenii 702, in a male Wistar rat model. Food and Chemical Toxicology, December 2003, vol. 41, no. 12, p. 1781-1787.

LIMA, O.G. Sobre uma interessante e pouco conhecida publicação de Paul Lindner acerca do emprego terapêutico de Zymomonas mobilis Kluyver e Van Niel, 1936 (Pseudomonas lindneri). Revista do Instituto de Antibióticos, 1958, vol. 1, p. 119-124.

LIMA O.G.; SCHUMACHER, I.E. and ARAÚJO, J.M. Further observations on the antagonist action of Zymomonas mobilis (Linder) (1928), Kluyver and Van Niel
(1936). Revista do Instituo de Antibióticos, 1969, vol. 8, no. 1, p. 19-48.

MÉDICI, M.; VINDEROLA, C.G. and PERDIGÓN, G. Gut mucosal immunomodulation by probiotic fresh cheese. International Dairy Journal, July 2004, vol. 14, no. 7, p. 611-618.

MONTESI, Alejandra; GARCIA-ALBIACH, Raimundo; POZUELO, María José; PINTADO, Concepción; GOÑI, Isabel and ROTGER, Rafael. Molecular and microbiological analysis of caecal microbiota in rats fed with diets supplemented either with prebiotics or probiotics. International Journal of Food Microbiology, February 2005, vol. 98, no. 3, p. 281-289.

O’BRIEN, John; CRITTENDEN, Ross; OUWEHAND, Arthur C. and SALMINEN, Seppo. Safety evaluation of probiotics. Trend Food Science and Technology, December 1999, vol. 10, no. 12, p. 418-424.

OLIVEIRA, Marcos Roberto; DA SILVA, Rui Sérgio S.F.; BUZATO, Joäo B. and CELLIGOI, Maria Antonia P.C. Study of levan production by Zymomonas mobilis using regional low-cost carbohydrate sources. Biochemical Engineering Journal, November 2007, vol. 37, no. 2, p. 177-183.

PERDIGÓN, G.; AGUERO, G.; ALVAREZ, S.; DE ALLORI, C.G. and HOLGADO, A.A.P.H. Effect of viable Lactobacillus casei feeding on the immunity of the mucosal and intestinal microflora malnutrished mice. Milchwissenschaft, 1995, vol. 50, no. 5, p. 251-256.

SAARELA, Maria; MOGENSEN, Gunnar; FONDÉN, Rangne; MÄTTÖ, Jaana and MATTILA-SANDHOLM, Tiina. Probiotic bacteria: safety, functional and technological properties. Journal of Biotechnology, December 2000, vol. 84, no. 3, p. 197-215.

SANTOS, Juliana F.M.; VASCONCELOS, Joelma; SOUZA, Joelma R.; COUTINHO Eridan M.; MONTENEGRO Silvia Maria L. and AZEVEDOXIMENES, Eulália. The effect of Zymomonas mobilis culture on experimental Shistosoma mansoni infection. Revista da Sociedade Brasileira de Medicina Tropical, November-December 2004, vol. 37, no. 6, p. 502-504.

SHU, Quan; ZHOU, Joseph S.; RUTHERFURD, Kay J.; BIRTLES, Mervyn J.; PRASAD, Jaya; GOPAL, Pramod K. and GILL, Harsharnjit S. Probiotic lactic acid bacteria (Lactobacillus acidophilus HN017, Lactobacillus rhamnosus HN001 and Bifidobacterium lactis HN019) have no adverse effects on the health of mice. International Dairy Journal, November 1999, vol. 9, no. 11, p. 831-836.

SOUZA, C. and SOUZA, L.A.G. Colpites and vulvovaginitis treatment using Zymomonas mobilis var. recifensis. Revista do Instituto de Antibióticos, 1973, vol. 13, no. 1-2, p. 85-87. 
SWINGS, Y. and DE LEY, J. The biology of Zymomonas.

Bacteriology Review, March 1977, vol. 41, no. 1, p. 1-46.

THOMKE, Sigvard and ELWINGER, Klas. Growth promotants in feeding pigs and poultry. III. Alternatives to antibiotic growth promotants. Annals of Zootechnology, 1998, vol. 47, p. 245-271.

VIGANTS, Armands; HICKE, Hans-Georg and MARX, Stefan Peter. A simple and efficient method for the purification of membrane-bound levansucrase from Zymomonas mobilis. Current Microbiology, June 2001, vol. 42, no. 6, p. 415-418.

VIIKARI, Liisa and BERRY, David R. Carbohydrate Metabolism in Zymomonas. Critical Reviews in Biotechnology, 1988, vol. 7, no. 3, p. 237-261.

YAMAMOTO, Yukiko; TAKAHASHI, Yuko; KAWANO, Mitsuyoshi; IIZUKA, Masaru; MATSUMOTO, Takashi; SAEKI, Shigeru and YAMAGUCHI, Hidemasa. In vitro digestibility and fermentability of levan and its hypocholesterolemic effects in rats. Journal of Nutritional Biochemistry, January 1999, vol. 10, no. 1, p. 13-18.

YOO, Sang-Ho; YOON, Eun Ju; CHA, Jaeho and LEE, Hyeon Guy. Antitumor activity of levan polysaccharides from selected microorganisms. International Journal of Biological Macromolecules, April 2004, vol. 34, no. 1-2, p. 37-41.

ZHOU, J.S.; SHU, Q.; RUTHERFURD, K.J.; PRASAD, J.; BIRTLES, M.J.; GOPAL, P.K. and GILL, H.S. Safety assessment of potential probiotic lactic acid bacterial strains Lactobacillus rhamnosus HN001, Lactobacillus acidophilus HN017 and Bifidobacterium lactis HN019 in BALB/c mice. International Journal of Food Microbiology, May 2000, vol. 56, no. 1, p. 87-96. 